\title{
Thymosin-Induced Suppression of Proliferative Response of Human Lymphocytes to Mitogens
}

\author{
Robert E. Wolf, Rheumatic Diseases Unit, Department of Internal Medicine, \\ University of Texas Health Science Center, Dallas, Texas 75235, and the \\ Veterans Administration Hospital, Dallas, Texas 75216
}

A B S TRACT The proliferative response of human peripheral blood lymphocytes to phytohemagglutinin, concanavalin $\mathrm{A}$, and pokeweed mitogen were suppressed by thymosin. Greatest decreases were observed when cells were preincubated with thymosin for $18 \mathrm{~h}$ before a 3 -d culture with mitogen in the presence of thymosin. However, significant suppression also occurred when lymphocytes were preincubated for $2 \mathrm{~h}$ and cultured with thymosin or preincubated for either 2 or $18 \mathrm{~h}$ and washed free of thymosin before culture. These effects were related to the concentration of thymosin and time of exposure to thymosin but not merely to a delay in the response to mitogen or to toxicity. The suppression of mitogen-induced proliferation by thymosin appeared to result from effects of thymosin on a suppressor cell because lymphocytes incubated with thymosin did not acquire increased responsiveness to mitogens as did cells incubated for $18 \mathrm{~h}$ in its absence and because mixing thymosin-pretreated lymphocytes with cells not preincubated with thymosin resulted in decreased responsiveness to photohemagglutinin.

\section{INTRODUCTION}

Differentiation of murine and human thymus-dependent ( $T$ ) lymphocytes has been induced by thymic extracts as assessed by expression of specific surface markers $(1,2)$, formation of spontaneous erythrocyte (E) rosettes (3-8), graft-vs.-host reactivity $(9,10)$, and sensitivity to $\mathrm{T}$ cell-specific antisera, azathioprine, or hydrocortisone $(1,3,9)$. In vivo effects of thymic extracts on both suppressor and helper $\mathrm{T}$ lymphocytes have been demonstrated in mice $(11,12)$. Recently,

Dr. Wolf is a recipient of a Veterans Administration Research Associateship. Address reprint requests to Dr. Wolf's present address, Section of Rhuematology, Department of Medicine, Louisiana State University School of Medicine in Shreveport, Shreveport, Louisiana 71130.

Received for publication 15 July 1978 and in revised form 11 December 1978. separate peptides with suppressor and helper activity have been isolated from thymosin fraction $5 .^{1}$

In vitro incubation of peripheral blood lymphocytes from healthy adults with thymosin altered the number of cells forming spontaneous $E$ rosettes. The degree of change varied inversely with the number of rosette-forming cells present in the absence of thymosin (13). Additionally, thymosin decreased in vitro stimulation of normal lymphocytes by allogeneic cells in individuals with relatively high responses but increased it in persons with lower responses (14). The mechanism through which such modulation was effected by thymosin was, however, not investigated.

The present studies were undertaken to assess modulation by thymosin of the in vitro proliferative response of peripheral blood lymphocytes from healthy adult humans to mitogens. The results demonstrated that thymosin significantly suppressed lymphocyte proliferation induced by phytohemagglutinin, concanavalin A, and pokeweed mitogen. Evaluation of the acquisition of increased responsiveness to mitogens and cell mixing studies suggested that the observed suppression was mediated by effects of thymosin on a suppressor cell.

\section{METHODS}

Preparation of lymphocytes. Peripheral blood from healthy donors was drawn into heparinized syringes. The blood was then diluted with an equal volume of normal saline, layered on sodium diatrizoate-Ficoll (Isolymph, GallardSchlesinger Manufacturing Corp., Carle Place, N. Y.) gradients at a $2: 1$ ratio of diluted blood to Isolymph and centrifuged at $400 \mathrm{~g}$ for $45 \mathrm{~min}$ at room temperature. The mononuclear cell layer was collected, washed three times, and diluted to a concentration of $1-2 \times 10^{6} \mathrm{cells} / \mathrm{ml}$ in RPMI 1640 containing glutamine, penicillin, and streptomycin.

Thymosin. Thymosin fraction 5 prepared from calf thymus (15) and calf spleen fraction 5 were provided by Dr. A. L. Goldstein (University of Texas Medical Branch). The lyophylized thymosin was reconstituted at a concentration of 10 $\mathrm{mg} / \mathrm{ml}$ and stored at $-20^{\circ} \mathrm{C}$.

\footnotetext{
${ }^{1}$ Goldstein, A. L. Personal communication.
} 
Lymphocyte cultures. To assess the effects of thymosin on mitogen-induced proliferation, $0.1 \mathrm{ml}$ of cells either treated or untreated with thymosin was added at a concentration of $5 \times 10^{5} / \mathrm{ml}$ in RPMI 1640 supplemented with glutamine, $10 \%$ human $\mathrm{AB}$ serum, penicillin and streptomycin to $0.1 \mathrm{ml}$ of mitogen in microtiter culture plates. The cultures were incubated at $37^{\circ} \mathrm{C}$ in a humidified $5 \% \mathrm{CO}_{2}$ and air atmosphere and pulsed with $\left[{ }^{3} \mathrm{H}\right]$ thymidine $(1 \mu \mathrm{Ci} /$ well $)$ for $18 \mathrm{~h}$ before harvest. Cells were collected on glass fiber filters $66 \mathrm{~h}$ after initiation of culture with a MASH II automated harvester (Microbiological Associates, Walkersville, Md.). The filters were placed in Bio-Vial containers (Beckman Instruments, Inc., Fullerton, Calif.) with $3 \mathrm{ml}$ of Aquasol scintillation fluid (New England Nuclear, Boston, Mass.) and counted in a Beckman liquid scintillation system (Beckman Instruments).

Results were expressed as percent response where percent response $=100-(\Delta \mathrm{cpm}$ of cultures with thymosin $/ \Delta \mathrm{cpm}$ of cultures without thymosin $\times 100) ; \Delta \mathrm{cpm}=\mathrm{cpm}$ of mitogen-stimulated cultures -cpm unstimulated cultures. A positive value indicated suppression of the lymphocyte response to mitogen and a negative value stimulation of lymphocyte responses to mitogens.

Mitogens used were as follows: phytohemagglutinin-P (PHA) ${ }^{2}$ (Difco Laboratories, Detroit, Mich.) at final dulutions of 1:2,000 and 1:10,000, concanavalin A (Con A) (Pharmacia Fine Chemicals, Piscataway, N. J.) at final concentrations of 25 and $5 \mu \mathrm{g} / \mathrm{ml}$, and pokeweed mitogen (PWM) (Difco Laboratories, Detroit, Mich.) at final dilutions of 1:100 and 1:500. The higher concentration of each mitogen induced optimum responses of the lymphocytes, whereas the lower concentration induced suboptimal stimulation.

Thymosin treatment. Lymphocytes were incubated with thymosin at a concentration of $200 \mu \mathrm{g} / \mathrm{ml}$ for either $2 \mathrm{~h}$ or $18 \mathrm{~h}$ and washed. These preincubated cells were then stimulated with mitogen both with and without thymosin (100 $\mu \mathrm{g} / \mathrm{ml}$ ) present in the final culture medium. Another aliquot of lymphocytes from each blood donor was preincubated and washed before culture without exposure to thymosin. In some experiments, spleen fraction 5 or fetal calf serum at the same concentrations was substituted for thymosin.

Dose response. To some cultures, thymosin was added in concentrations of $100,50,25,12$, and $6 \mu \mathrm{g} / \mathrm{ml}$ to evaluate the relationship between dose and effect of thymosin on the response of lymphocytes to PHA. Culture conditions were otherwise identical to those described above.

Sequence of addition of thymosin. In some cases, thy$\operatorname{mosin}(100 \mu \mathrm{g} / \mathrm{ml})$ was added at $-2,0,2,24$, and $48 \mathrm{~h}$ of culture relative to the addition of $\mathrm{PHA}$ at zero time. The cultures were incubated, pulsed, and harvested as described above.

Increased responsiveness to mitogens after preincubation. Recently, increased responsiveness of human peripheral blood lymphocytes to Con A has been reported after a 24-h preincubation period in culture (16). In the present report, data from four experiments were calculated to evaluate the effects of thymosin on the acquisition of increased responsiveness of peripheral blood lymphocytes to Con A after a preliminary preincubation period. Results were expressed as $\Delta 18 / \Delta 2$, where $\Delta 18=\Delta \mathrm{cpm}$ after an 18 -h preincubation and $\Delta 2=\Delta \mathrm{cpm}$ after $2 \mathrm{~h}$ of incubation. $\Delta 18 / \Delta 2$ was determined both with and without thymosin present. After preincubation, cells were washed and cultured as described above.

Lymphocyte mixing studies. In five experiments, lymphocytes preincubated in the presence of thymosin $(200 \mu \mathrm{g} / \mathrm{ml})$

${ }^{2}$ Abbreviations used in this paper: Con A, concanavalin $A$; $E$, expected incorporation; $O$, observed incorporation; PHA, phytohemagglutinin-P; PWM, pokeweed mitogen. for $18 \mathrm{~h}$ were mixed with autologous cells preincubated in the absence of thymosin to determine the suppressive effects of the thymosin-treated cells on untreated lymphocytes. All cells were washed after preincubation. Triplicate cultures stimulated with PHA 1:2,000 were incubated without additional thymosin, pulsed, and harvested as described above and contained combinations of cells as follows: $1 \times 10^{5}$ thymosin-pretreated alone, $1 \times 10^{5}$ untreated alone, $0.5 \times 10^{5}$ thymosin-treated plus $0.5 \times 10^{5}$ untreated, and $0.25 \times 10^{5}$ thymosin-treated plus $0.75 \times 10^{5}$ untreated. Incorporation expected $(E)$ in the absence of any influence of thymosintreated lymphocytes on the untreated cells was determined by extrapolation along a line connecting plotted observed values for $1 \times 10^{5}$ untreated cells alone and $1 \times 10^{5}$ thymosintreated lymphocytes. For example, E for $0.5 \times 10^{5}$ untreated plus $0.5 \times 10^{5}$ thymosin-treated cells fell at the midpoint of the line. Observed $(\mathrm{O})$ incorporation for cell mixtures was determined experimentally. Incorporation was expressed as $\Delta \mathrm{E}$ $=\mathrm{E}$ for each mixture minus incorporation by $1 \times 10^{5}$ thymosintreated cells and $\Delta \mathrm{O}=0$ for each mixture minus incorporation by $1 \times 10^{5}$ thymosin-treated cells. Thus, the $\Delta$-values represented $\left[{ }^{3} \mathrm{H}\right]$ thymidine incorporated above maximum suppression by preincubation with thymosin. Suppression was expressed as both absolute $(\Delta \mathrm{E}-\Delta \mathrm{O})$ and relative (percent suppression $=100-(\Delta \mathrm{O} / \Delta \mathrm{E} \times 100)$ differences.

Statistical analysis. The statistical significance of alteration of responses to mitogens by thymosin and dose-response effect of thymosin were analyzed using Student's $t$ test for paired data.

\section{RESULTS}

Suppression of mitogen-induced DNA synthesis by thymosin. Proliferation of peripheral blood lymphocytes in response to both optimal and suboptimal concentrations of all mitogens was significantly suppressed by thymosin (Table I). This effect was most marked when cells were preincubated with thymosin for $18 \mathrm{~h}$ before the addition of the mitogens and cultured in the presence of thymosin. The degree of suppression was decreased but still significant when thymosin was omitted from the cultures of cells preincubated with thymosin for $18 \mathrm{~h}$. In cultures containing lymphocytes preincubated with thymosin for $2 \mathrm{~h}$, the suppressive effect was similar in magnitude whether or not thymosin was present in the culture medium but was smaller than observed after an 18 - $\mathrm{h}$ preincubation.

Incorporation of $\left[{ }^{3} \mathrm{H}\right]$ thymidine in unstimulated cultures was minimal and unaffected by preincubation of lymphocytes with thymosin. Mean counts per minute \pm SEM were $268 \pm 8$ for cells incubated and cultured in the absence of thymosin, $273 \pm 9$ for cells preincubated with thymosin for $18 \mathrm{~h}$ and cultured without thymosin, and $311 \pm 9$ for cells with thymosin present during both 18-h preincubation and culture. These differences were not significant by paired $t$ test analysis. Addition of spleen fraction 5 or fetal calf serum to cultures did not significantly reduce proliferative responses of lymphocytes from five individuals to PHA. After a 2-h preincubation with spleen fraction 5 and culture in the presence of this tissue extract, mean per- 
TABLE I

Effect of Thymosin on Mitogen-Induced Proliferation of Human Peripheral Blood Lymphocytes

\begin{tabular}{|c|c|c|c|c|c|c|c|}
\hline \multirow{3}{*}{$\begin{array}{l}\text { Preincubation } \\
\text { with thymosin }\end{array}$} & \multirow{3}{*}{$\begin{array}{l}\text { Thymosin in } \\
\text { culture medium* }\end{array}$} & \multicolumn{6}{|c|}{ Mean percent suppression \pm SEM $\ddagger$} \\
\hline & & \multicolumn{2}{|c|}{ PHA } & \multicolumn{2}{|c|}{ Con $\mathbf{A}$} & \multicolumn{2}{|c|}{ PWM } \\
\hline & & $1: 2,000$ & $1: 10,000$ & 25 & 5 & $1: 100$ & $1: 500$ \\
\hline$h$ & & \multicolumn{6}{|c|}{$\mu \mathrm{g} / \mathrm{ml}$} \\
\hline 2 & + & $\begin{array}{c}26.7 \pm 4.2 \\
(13) \S \\
P<0.001^{\prime \prime}\end{array}$ & $\begin{array}{c}45.1 \pm 5.7 \\
(13) \\
P<0.001\end{array}$ & $\begin{array}{c}23.4 \pm 6.2 \\
(13) \\
P<0.01\end{array}$ & $\begin{array}{c}25.2 \pm 7.0 \\
(13) \\
P<0.01\end{array}$ & $\begin{array}{c}22.0 \pm 6.1 \\
(13) \\
P<0.01\end{array}$ & $\begin{array}{c}27.3 \pm 5.3 \\
\quad(13) \\
P<0.001\end{array}$ \\
\hline 2 & 0 & $\begin{array}{c}23.2 \pm 5.1 \\
\quad(13) \\
P<0.001\end{array}$ & $\begin{array}{c}34.1 \pm 4.8 \\
\quad(13) \\
P<0.001\end{array}$ & $\begin{array}{c}30.1 \pm 7.7 \\
(13) \\
P<0.01\end{array}$ & $\begin{array}{c}23.2 \pm 8.5 \\
\quad(13) \\
P<0.05\end{array}$ & $\begin{array}{c}15.5 \pm 6.4 \\
(13) \\
P<0.05\end{array}$ & $\begin{array}{c}18.2 \pm 6.4 \\
(13) \\
P<0.05\end{array}$ \\
\hline 18 & + & $\begin{array}{c}48.1 \pm 7.7 \\
(9) \\
P<0.001\end{array}$ & $\begin{array}{c}76.2 \pm 4.6 \\
(9) \\
P<0.001\end{array}$ & $\begin{array}{c}67.8 \pm 4.2 \\
\quad(9) \\
P<0.001\end{array}$ & $\begin{array}{c}72.1 \pm 4.0 \\
\quad(9) \\
P<0.001\end{array}$ & $\begin{array}{c}62.0 \pm 6.0 \\
(9) \\
P<0.001\end{array}$ & $\begin{array}{c}63.2 \pm 7.3 \\
(9) \\
P<0.001\end{array}$ \\
\hline 18 & 0 & $\begin{array}{c}20.8 \pm 6.7 \\
(13) \\
P<0.01\end{array}$ & $\begin{array}{c}41.8 \pm 5.4 \\
(13) \\
P<0.001\end{array}$ & $\begin{array}{c}33.6 \pm 8.4 \\
(9) \\
P<0.01\end{array}$ & $\begin{array}{c}38.6 \pm 6.6 \\
(9) \\
P<0.001\end{array}$ & $\begin{array}{c}19.5 \pm 6.2 \\
(13) \\
P<0.05\end{array}$ & $\begin{array}{c}29.3 \pm 8.3 \\
(13) \\
P<0.01\end{array}$ \\
\hline
\end{tabular}

* After preincubation, cells were washed and stimulated with mitogen for $3 \mathrm{~d}$ either in the presence $(+)$ or absence $(0)$ of thymosin.

$\ddagger$ Percent suppression, $100-(\Delta \mathrm{cpm}$ cells preincubated with thymosin/ $\Delta \mathrm{cpm}$ cells preincubated without thymosin $\times 100)$.

$\$$ Number of individuals tested given in parentheses.

" $P$ values determined by Student's $t$ test for paired data.

cent suppression $\pm \mathrm{SEM}$ was $-10.5 \pm 1.7 \%$, a minimal stimulatory effect, for the optimal concentration of PHA, and $6.5 \pm 4.8$ for the suboptimal mitogen concentration.

Effect of thymosin on proliferative responses to different mitogens. The degree of thymosin-induced suppression of proliferation was inversely related to PHA concentration but similar at both concentrations of Con A and PWM employed (Table I). Consistently greater suppression of PHA responses was observed at the suboptimal concentration of PHA employed regardless of length of preincubation with thymosin or its presence or absence in the culture medium. The effect of thymosin on responses to Con A and PWM was similar at both optimal and suboptimal concentrations (Table I).

Effect of thymosin concentration on suppression of PHA-induced proliferation. To evaluate the doseresponse effect of thymosin on lymphocyte proliferation, mononuclear cells from six individuals were preincubated with thymosin for $2 \mathrm{~h}$ and subsequently cultured in its presence at concentrations of $6,12,25$, 50 , and $100 \mu \mathrm{g} / \mathrm{ml}$. Percent suppression was calculated for each concentration of thymosin by comparison with cultures not containing thymosin. As shown in Table II, the degree of suppression increased at concentrations of thymosin between 6 and $25 \mu \mathrm{g} / \mathrm{ml}$ but plateaued thereafter. This pattern was qualitatively similar at both PHA concentrations although quantitative differences were observed.
Kinetics of PHA response in the presence and absence of thymosin. To investigate the possibility that the suppression observed after $66 \mathrm{~h}$ in culture was related to altered kinetics of mitogen-induced proliferation, cells preincubated for $2 \mathrm{~h}$ with thymosin and then cultured with PHA in the presence of thymosin without washing before addition of the mitogen were harvested 18, 42, 66, and $90 \mathrm{~h}$ after the addition of PHA. Cells not exposed to thymosin were processed in

TABLE II

Effect of Thymosin Concentration on Response to PHA

\begin{tabular}{ccccc}
\hline \multirow{2}{*}{$\begin{array}{c}\text { Concentration } \\
\text { of thymosin }\end{array}$} & PHA 1:2,000 & $P$ value $\$$ & PHA 1:10,000 & $P$ value \\
\cline { 2 - 5 } & & & & \\
\hline$g / m l^{*}$ & & & & \\
100 & $24.3 \pm 4.1$ & $<0.01$ & $47.8 \pm 6.3$ & $<0.01$ \\
50 & $23.8 \pm 7.3$ & $<0.05$ & $50.2 \pm 4.6$ & $<0.01$ \\
25 & $20.0 \pm 6.5$ & $<0.05$ & $47.3 \pm 4.6$ & $<0.01$ \\
12 & $13.8 \pm 5.1$ & $<0.05$ & $33.4 \pm 10.4$ & $<0.05$ \\
6 & $-5.2 \pm 9.2$ & NS & $13.4 \pm 8.9$ & NS \\
\hline
\end{tabular}

* Thymosin present during $2 \mathrm{~h}$ preincubation and throughout subsequent $3 \mathrm{~d}$ culture with PHA. Cells were washed after preincubation.

$\ddagger$ Percent suppression, $100-(\Delta \mathrm{cpm}$ of cultures with thy$\operatorname{mosin} / \Delta \mathrm{cpm}$ of cultures without thymosin $\times 100)$; mean of six experiments.

$\S$ Student's $t$ test for paired data. 
parallel. Responses were suppressed by thymosin throughout the period examined except after only $18 \mathrm{~h}$ of culture, at which time there was no stimulation by PHA (Fig. 1). However, no other alteration of the kinetic curve was noted, indicating that the observed suppression was not related to the duration of culture. Similar results were obtained with both concentrations of PHA used.

Effect of sequence of addition of thymosin. In five experiments, thymosin was added to cultures at -2 , $0,2,24$, and $48 \mathrm{~h}$ relative to the addition of PHA. As shown in Fig. 2, thymosin added to cultures either $2 \mathrm{~h}$ before or simultaneously with PHA induced similar degrees of suppression of proliferation. When added 2 or $24 \mathrm{~h}$ after PHA, thymosin was suppressive but less than if introduced earlier. Thymosin had no effect on proliferation when added at $48 \mathrm{~h}$ at the time of the $\left[{ }^{3} \mathrm{H}\right]$ thymidine pulse. These results indicate that thymosin affects an event early in the initiation of proliferation induced by PHA because the greatest suppression was detected when thymosin was added before or simultaneously with PHA. Additionally, thymosin was not toxic because addition at $48 \mathrm{~h}$ did not alter the proliferative response to PHA and because the introduction of thymosin into cultures as early as $2 \mathrm{~h}$ after the addition of PHA decreased its capacity to suppress proliferation. Thymosin-induced suppression was qualitaiively similar at both PHA concentrations.

Effect of thymosin on acquisition of increased responsiveness to mitogens after preincubation. Bres-

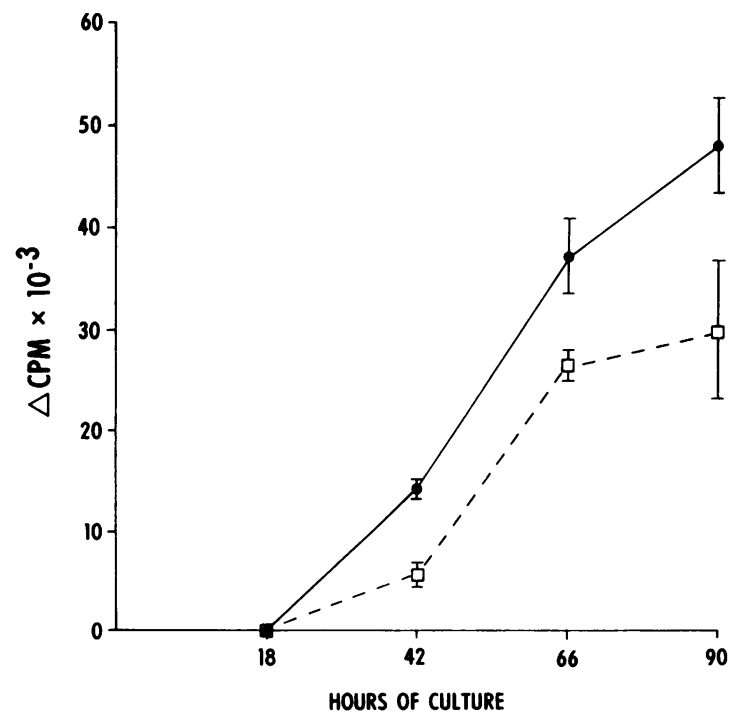

FIGURE 1 Effect of thymosin on kinetics of response to PHA after varying periods of culture. Lymphocytes were preincubated for $2 \mathrm{~h}$ with thymosin and then cultured in the presence $(\square)$ or absence $(0)$ of thymosin. PHA $(1: 2,000)$ was added at zero hours, and cultures were harvested at times indicated after an $18-\mathrm{h}$ pulse with $\left[{ }^{3} \mathrm{H}\right]$ thymidine. Vertical bars indicate the SEM.

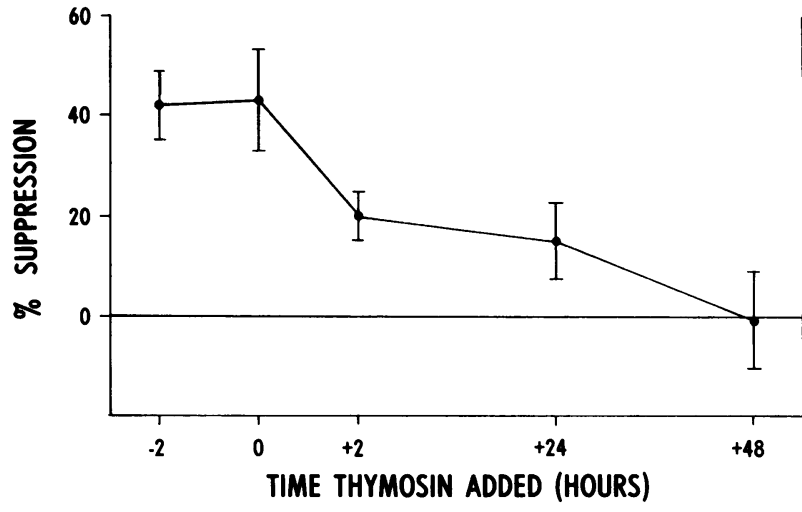

Figure 2 Thymosin-induced suppression of response to PHA. Thymosin was added at the different times indicated to cultures stimulated with PHA $(1: 10,000)$ at zero hours and harvested after $66 \mathrm{~h}$ of culture. Percent suppression, $100-(\Delta \mathrm{cpm}$ of cultures with thymosin/ $\Delta$ cpm of cultures without thymosin $\times 100$ ). Vertical bars indicate the SEM.

nihan and Jasin (16) and Rich and Pierce (17) observed an increased proliferative response to Con $\mathrm{A}$ when human peripheral blood mononuclear cells were incubated before stimulation. The increased response was attributed to the loss of a short-lived suppressor cell during incubation. Accordingly, experiments were carried out to determine whether thymosin would prevent the loss of this suppressor cell as manifest by a failure to observe an increased proliferative response to Con A after incubation of cultures in the presence of thymosin. As shown in Table III, cells

TABLE III

Effect of Preincubation with Thymosin on Acquisition of Increased Responsiveness to Con A

\begin{tabular}{cccc}
\hline & & \multicolumn{2}{c}{$\frac{\Delta 18 \mathrm{~h}^{*}}{\Delta 2 \mathrm{~h} t}$} \\
\cline { 3 - 4 } $\begin{array}{c}\text { Concentration } \\
\text { of Con A }\end{array}$ & Experiment & $\begin{array}{c}\text { Without } \\
\text { thymosin }\end{array}$ & $\begin{array}{c}\text { With } \\
\text { thymosin }\end{array}$ \\
\hline$\mu g / m l$ & & & \\
25 & 1 & 2.3 & 0.7 \\
& 2 & 3.7 & 2.4 \\
& 3 & 4.2 & 2.4 \\
& 4 & 1.9 & 1.5 \\
5 & Mean \pm SEM & $3.0 \pm 0.5$ & $1.7 \pm 0.4$ \\
& 1 & 1.8 & 0.8 \\
& 2 & 7.6 & 1.0 \\
& 4 & 4.6 & 2.0 \\
& 4 & 2.1 & 2.0 \\
& Mean \pm SEM & $4.0 \pm 1.3$ & $1.4 \pm 0.3$ \\
& & &
\end{tabular}

$* \Delta 18 \mathrm{~h}, \Delta \mathrm{cpm}$ of cells preincubated with or without thymosin for $18 \mathrm{~h}$ and washed before 3-d culture with Con A.

$\ddagger \Delta 2 \mathrm{~h}, \Delta \mathrm{cpm}$ of cells preincubated with or without thymosin for $2 \mathrm{~h}$ and washed before 3 -d culture with Con $\mathrm{A}$. 
preincubated for $18 \mathrm{~h}$ without thymosin acquired an increased responsiveness relative to those incubated for $2 \mathrm{~h}$ before culture. Parallel experiments in which the lymphocytes were preincubated for 2 and $18 \mathrm{~h}$ in the presence of thymosin and washed before 3-d stimulation with Con A demonstrated reduced enhancement of responses to this mitogen after the 18-h incubation period (Table III). This effect of thymosin was demonstrable at both Con A concentrations tested.

Suppression of proliferative response of untreated lymphocytes to mitogens by thymosin-preincubated cells. Lymphocytes preincubated in the presence and absence of thymosin and washed were cultured at the concentrations described. Table IV shows that observed proliferative responses were suppressed below expected values in all five experiments, when equal numbers of cells preincubated in the presence and absence of thymosin were cultured together. When a minority of cells in culture had been preincubated with thymosin, suppression was observed in four of five experiments with stimulation in the other one (Table V). These results provided more direct evidence for induction of suppressor cells by thymosin.

\section{DISCUSSION}

In these studies, the effects of thymosin on mitogeninduced proliferation of peripheral blood lymphocytes from healthy adult humans were evaluated. Responses to both optimal and suboptimal concentrations of PHA, Con A, and PWM were significantly suppressed by

\section{TABLE IV}

Suppression of Responsiveness of Untreated Lymphocytes to PHA by Equal Numbers of Autologous Thymosin-Treated Cells*

\begin{tabular}{crrrc}
\hline Experiment & \multicolumn{1}{c}{$\Delta \mathrm{E} \downarrow$} & $\Delta \mathrm{O} \S$ & $\Delta \mathrm{E}-\Delta \mathrm{O}$ & Suppression" \\
\hline & $c p m$ & \multicolumn{1}{c}{$c p m$} & \multicolumn{1}{c}{$c p m$} & $\%$ \\
1 & 15,741 & 8,836 & 6,905 & 44 \\
2 & 38,640 & 6,081 & 32,559 & 84 \\
3 & 11,217 & 3,961 & 7,256 & 65 \\
4 & 28,426 & 22,471 & 5,955 & 21 \\
5 & 7,875 & 1,400 & 6,475 & 82 \\
\hline
\end{tabular}

* Lymphocytes were incubated in the absence or presence of thymosin at a concentration of $200 \mu \mathrm{g} / \mathrm{ml}$ for $18 \mathrm{~h}$ and washed. Cultures containing $0.5 \times 10^{5}$ untreated and 0.5 $\times 10^{5}$ thymosin-treated cells were stimulated with PHA $1: 2,000$ for $3 \mathrm{~d}$ with $\left[{ }^{3} \mathrm{H}\right]$ thymidine pulse during final $20 \mathrm{~h}$.

ई $\Delta \mathrm{E}$, expected counts per minute of $\left[{ }^{3} \mathrm{H}\right]$ thymidine above maximum suppression incorporated by untreated cells in mixtures.

$\S \Delta \mathrm{O}$, observed counts per minute of $\left[{ }^{3} \mathrm{H}\right]$ thymidine above maximum suppression incorporated by untreated cells in mixtures.

" Percent suppression, $100-(\Delta \mathrm{O} / \Delta \mathrm{E} \times 100)$.
TABLE V

Suppression of Responsiveness of Untreated Lymphocytes to PHA in Cultures Containing More Untreated than Thymosin-Treated Cells*

\begin{tabular}{crrrr}
\hline Experiment & \multicolumn{1}{c}{$\Delta \mathrm{E} \downarrow$} & \multicolumn{1}{c}{$\Delta \mathrm{O} \S$} & \multicolumn{1}{c}{$\Delta \mathrm{E}-\Delta \mathrm{O}$} & Suppression" \\
\hline & \multicolumn{1}{c}{$c p m$} & \multicolumn{1}{c}{$c p m$} & \multicolumn{1}{c}{$c p m$} & $\%$ \\
1 & 10,495 & 7,314 & 3,181 & 30 \\
2 & 25,759 & 12,676 & 13,084 & 51 \\
3 & 7,478 & 2,015 & 5,463 & 73 \\
4 & 18,950 & 26,379 & $-7,429$ & -39 \\
5 & 5,250 & 300 & 4,950 & 94 \\
\hline
\end{tabular}

* Preincubation and culture were the same as for Table IV except that cultures contained $0.75 \times 10^{5}$ untreated and $0.25 \times 10^{5}$ thymosin-treated cells.

$\ddagger \Delta \mathrm{E}$, expected incorporation by untreated cells as in Table IV.

$\S \Delta \mathrm{O}$, observed incorporation by untreated cells as in Table IV.

"Percent suppression, $100-(\Delta \mathrm{O} / \Delta \mathrm{E} \times 100)$.

thymosin. Decreased responsiveness was observed when cells were preincubated with thymosin for $2 \mathrm{~h}$ or $18 \mathrm{~h}$, washed, and subsequently cultured with the mitogens for $3 \mathrm{~d}$ with or without addition of thymosin. Maximum suppression occurred when lymphocytes were preincubated for $18 \mathrm{~h}$ and then cultured with thymosin. It was concluded that diminution of responsiveness was possibly mediated by effects of thymosin on $\mathrm{T}$ lymphocytes because the mitogens used induce proliferation of $T$ cells (18) and because thymosin has been reported to affect only $T$ cells $(19,20)$.

The degree of suppression was also dependent on mitogen concentration for PHA but not for Con A and PWM. Responses to PHA were suppressed by thymosin more than responses to Con A or PWM. Responses to suboptimal concentrations of PHA were consistently decreased to a greater degree than those to optimal concentrations. This observation suggested that at least quantitative differences exist in the modulation of $\mathrm{T}$ cell proliferation induced by different mitogens. Additionally, a limited dependency of suppression on thymosin concentration was detected. Suppression of PHA responses increased directly with thymosin concentration between 6 and $25 \mu \mathrm{g} / \mathrm{ml}$ but plateaued thereafter at the two mitogen concentrations used. However, the effect of thymosin on the response to the optimal PHA concentration never approached the degree of suppression observed at a suboptimal concentration. The effect of thymosin on the PHA response measured after varying periods of culture was investigated to determine whether thymosin induced a consistent suppression throughout culture or whether it only produced a delay in proliferation with a shift of the normal kinetic curve. It was demonstrated that 
the proliferative response of lymphocytes to PHA was consistently decreased by thymosin through $4 \mathrm{~d}$ of culture. In fact, between days 3 and 4 of culture, there was a smaller increase in proliferation of lymphocytes cultured with thymosin than those cultured in the absence of thymosin, indicating that thymosin altered the ability of lymphocytes to respond rather than merely shifting the kinetics of the response.

When thymosin was added to cultures at various time intervals relative to the addition of mitogen, greatest suppression was observed when it was added either $2 \mathrm{~h}$ before or at the same time as the PHA. The addition of thymosin 2 or $24 \mathrm{~h}$ after stimulation resulted in a lesser degree of suppression, and there was no effect on responsiveness when it was introduced after $48 \mathrm{~h}$ of culture at the time of the $\left[{ }^{3} \mathrm{H}\right]$ thymidine pulse. These results indicated that thymosin modified some event early in the time-course of PHA stimulation. They also indicated that thymosin was not toxic as addition late in culture did not alter proliferation.

The possibility that the decreased responses to mitogens were related to the differentiation of a suppressor cell by thymosin was investigated by assessing the effect of thymosin on the acquisition of increased responsiveness by preincubation in a maner similar to that used by Bresnihan and Jasin (16) and Rich and Pierce (17). The latter authors provided evidence that a short-lived suppressor of T-cell function was lost during a 24-h incubation period. Accordingly, cells were preincubated in the presence or absence of thymosin and washed before culture with mitogen. The ratios of responses after $2 \mathrm{~h}$ and $18 \mathrm{~h}$ of preincubation were determined as a measure of suppressor cell depletion and compared with cells incubated without or with thymosin present. The augmentation of proliferation previously observed was decreased or abolished by preincubation with thymosin, suggesting that thymosin induced differentiation of a suppressor cell from precursors and prevented the acquisition of increased responsiveness resulting from the loss of a subpopulation of suppressor cells which modulate T-lymphocyte responses. More direct evidence for the induction or differentiation of a suppressor cell by thymosin was obtained from experiments in which thymosintreated lymphocytes were combined with autologous untreated cells and stimulated with PHA. When equal numbers of treated and untreated cells were present, expected responses were suppressed by $21-84 \%$ in all five experiments (Table IV). When there were more untreated than treated cells in culture, suppression of $30-94 \%$ was observed in four of five experiments. These studies indicate the induction by thymosin of a suppressor cell in normal individuals. Recently, induction by thymosin of Con A-activatable cells which suppressed mixed leukocyte culture responses has been reported in patients with systemic lupus erythematosus who lacked such a suppressor cell in the absence of thymosin (21).

It has previously been demonstrated that thymosin elevates cyclic guanosine $5^{\prime}$-monophosphate levels (22) and that increased cyclic nucleotide levels decrease responses to PHA (23). However, because the effect of cyclic nucleotides on mitogen-induced proliferation was readily reversible by removal of these agents before culture (23), it appears unlikely that such a mechanism was responsible for the suppression observed in the present studies as removal of thymosin did not affect the degree of suppression, at least after a $2 \mathrm{~h}$ preincubation. It may be concluded, therefore, that suppression by thymosin of mitogen-induced proliferation of normal adult human peripheral blood lymphocytes has been demonstrated in these experiments. It appears that this suppression was mediated by thymosin-induced differentiation of suppressor cells from precursors although the characteristics of the suppressor cell were not established.

\section{ACKNOWLEDGMENTS}

Thymosin fraction 5 was kindly provided by Dr. Allan L. Goldstein, Division of Biochemistry, the University of Texas Medical Branch, Galveston, Tex. The author thanks Dr. Morris Ziff for his advice and manuscript review and Mrs. Rita Douglass for her capable technical assistance.

These investigations were supported by a Veterans Administration Research Associateship, U. S. Public Health Service grants AM 09989, AM 05154, AM 18505, and an Arthritis Foundation Clinical Study Center grant.

\section{REFERENCES}

1. Bach, J. F., M. Dardenne, A. L. Goldstein, A. Guha, and A. White. 1971. Appearance of T-cell markers in bone marrow rosette-forming cells after incubation with thymosin, a thymic hormone. Proc. Natl. Acad. Sci. U. S. A. 68: 2734-2738.

2. Basch, R. S. and G. Goldstein. 1974. Induction of T-cell differentiation in vitro by thymin, and purified polypeptide hormone of the thymus. Proc. Natl. Acad. Sci. U. S. A. 71: 1474-1478.

3. Touraine, J. L., G. S. Incefy, F. Touraine, Y. M. Rho, and R. A. Good. 1974. Differentiation of human bone marrow cells into $\mathrm{T}$ lymphocytes by in vitro incubation with thymic extracts. Clin. Exp. Immunol. 17: 151-158.

4. Vogel, J. E., G. S. Incefy, and R. A. Good. 1975. Differentiation of population of peripheral blood lymphocytes into cells bearing sheep erythrocyte receptors in vitro by human thymic extract. Proc. Natl. Acad. Sci. U. S. A. 72: 1175-1178.

5. Wara, D. W., A. L. Goldstein, N. E. Doyle, and A. J. Ammann. 1975. Thymosin activity in patients with cellular immunodeficiency. N. Engl. J. Med. 292: 70-74.

6. Sakai, H., J. J. Costanzi, D. F. Loukas, Jr., R. G. Gagliano, S. E. Ritzmann, and A. L. Goldstein. 1975. Thymosin-induced increase in E-rosette-forming capacity 
of lymphocytes in patients with malignant neoplasms. Cancer. 36: 974-976.

7. Wybran, J., A. S. Levine, H. H. Fudenberg, and A. L. Goldstein. 1975. Thymosin: Effects on normal human blood T-cells. Ann. N. Y. Acad. Sci. 249: 300-307.

8. Aiuti, F., V. Schirrmacher, P. Ammirati, and M. Ficrilli. 1975. Effect of thymus factor on human precursor $T$ lymphocytes. Clin. Exp. Immunol. 20: 499-503.

9. Law, L. W., A. L. Goldstein, and A. White. 1968. Influence of thymosin on immunological competence of lymphoid cells from thymectomized mice. Nature (Lond.). 219: 1391-1392.

10. Trainin, N., Y. Levo, and V. Rotter. 1974. Resistance to hydrocortisone conferred upon thymocytes by a thymic humoral factor. Eur. J. Immunol. 4: 634-637.

11. Dauphinee, M. J., and N. Talal. 1975. Reversible restoration by thymosin of antigen-induced depression of spleen DNA synthesis in NZB mice. J. Immunol. 114: 1713-1716.

12. Bach, M. A., and P. Niaudet. 1976. Thymic function in NZB mice. II. Regulatory influence of a circulating thymic factor on antibody production against polyvinylpyrrolidone in NZB mice. J. Immunol. 117: $760-764$.

13. Kenady, D. E., P. B. Chretien, C. Potvin, R. M. Simon, J. C. Alexander, Jr., and A. L. Goldstein. 1977. Effect of thymosin in vitro on $\mathrm{T}$ cell levels during radiation therapy. Cancer. 39: 642-652.

14. Schafer, L. A., A. L. Goldstein, J. V. Gutterman, and E. M. Hersh. 1976. In vitro and in vivo studies with thymosin in cancer patients. Ann. N. Y. Acad. Sci. 277: 609-620.

15. Hooper, J. A., M. C. McDaniel, G. B. Thurman, G. H. Cohen, R. S. Schulof, and A. L. Goldstein. 1975. Purification and properties of bovine thymosin. Ann. N. Y. Acad. Sci. 249: 125-144.
16. Bresnihan, B., and H. E. Jasin. 1977. Suppressor function of peripheral blood mononuclear cells in normal individuals and in patients with systemic lupus erythematosus. J. Clin. Invest. 59: 106-116.

17. Rich, R. R., and C. W. Pierce. 1973. Biological expressions of lymphocyte activation. I. Effects of phytomitogens on antibody synthesis in vitro. J. Exp. Med. 137: $127-139$.

18. Chess, L., R. P. MacDermott, and S. F. Schlossman. 1974. Immunologic functions of isolated human lymphocyte subpopulations. I. Quantitative isolation of human $\mathrm{T}$ and $\mathrm{B}$ cells and response to mitogens. J. Immunol. 113: 1113-1127.

19. Goldstein, A. L., J. A. Hooper, R. S. Schulof, G. H. Cohen, G. B. Thurman, M. C. McDaniel, A. White, and M. Dardenne. 1974. Thymosin and the immunopathology of aging. Fed. Proc. 33: 2053-2056.

20. Scheid, M. P., M. K. Hoffman, K. Komuro, V. Hammerling, J. Abbott, E. A. Boyse, G. H. Cohen, J. A. Hooper, R. S. Schulof, and A. L. Goldstein. 1973. Differentiation of $\mathrm{T}$ cells induced by preparations from thymus and nonthymus agents. The determined state of the precursor cell. J. Exp. Med. 138: 1027-1032.

21. Horowitz, S., W. Borcherding, A. V. Moorthy, R. Chesney, H. Schulte-Wissermann, and R. Hong. 1977. Induction of suppressor $\mathrm{T}$ cells in systemic lupus erythematosus by thymosin and cultured thymic epithelium. Science (Wash. D. C.). 197: 999-1001.

22. Naylor, P. H., G. B. Thurman, and A. L. Goldstein. 1977. Thymosin induced increase in cyclic GMP in murine lymphocytes. Fed. Proc. 36: 688.

23. Smith, J. W., A. L. Steiner, and C. W. Parker. 1971. Human lymphocyte metabolism. Effects of cyclic and noncyclic nucleotides on stimulation by phytohemagglutinin. J. Clin. Invest. 50: 442-448. 